\title{
WOODLOT PROMOTION IN ALBERTA
}

\section{I. CROSSLEY 1}

The woodlot situation in Alberta is complicated by the fact that the province is made up of three distinct regions, each of which presents a different problem. The plains lie to the south and, to all intents and purposes, they are devoid of tree growth. The forested lands are in the north and along the eastern slopes of the mountains. Between forested land and plain extends the park belt which, while strictly agricultural, is characterized by, and derives its name from scattered groves of scrubby poplar and willow. In addition there is the great Peace River block to the northwest. It is entirely surrounded with forested land but is itself a combination of forest, parkland and plain.

Trees can be grown successfully on the plains, provided that the effect of the natural lack of moisture is ameliorated by continued cultivation. Such husbandry is, however, expensive business, only warranted when considering the need for shelter rather than cellulose.

A similar situation exists in the park belt, although to a somewhat lesser degree; the heavier precipitation received by this area results in a less critical moisture regime. Nevertheless, plantations cannot be entirely neglected or failure will result. To the best of my knowledge no serious attempt has been made to scientifically manage the natural aspen and willow groves. In the first place the end product would not have much commercial value, and in the second place the land on which they are growing is usually far more valuablc producing cereal and forage crops. There is a small but none-the-less influential opinion among local foresters that would discourage farmers from clearing their land of these scattered groves on the gounds that they assist in breaking the force of the wind, prevent soil drifting and desiccation, accumulate snow during the winter, and harbor bird life. I claim allegiance to an equally small but determined group which, while admitting all the above benefits that trees on the land provide, would encourage the removal of such groves on the grounds that their haphazard natural arrangement is seldom to the farmer's advantage in the cultivation of his land, nor are they situated to provide maximum protection from the force of the wind. The removal of these natural groves from a farm management point of view would increase the agricultural Fotential, provided that, at the same time, shelterbelts were artificially established and so arranged as to give maximum protection commensurate with the removal of the minimum amount of land from cultivation. It should be emphasized that this latter group recognizes the desirability of retlining the natural groves where they are strategically located. This would include fence row belts, and groves on non-arable land such as erodable hillsides and coulees. Under such conditions it would be good silviculture to underplant with conifers in order to introduce a wider variety of utility trees and improve the quality of the product.

\footnotetext{
1. Member of the Woodlot Management Committee, C.I.F., at Calgary, Alberta.
} 
It will be obvious at this point that the prairie farm differs radically from the average farm in either eastern Canada or British Columbia. According to Nelson Adams, extension forester in the province of New Brunswick, the average farm in that province contains 120 acres of which 80 acres is forested. and suitable only for growing trees-(italics provided). In the first place none or very little of any prairie farm is forested, and few woodlots can stand the financial burden of artificial establishment. In the second place, very little of the same farm is non-arable. What little non-arable land there is is usually scattered in the form of small, humid, alkaline depressions. The woodlot in the accepted sense of the word therefore appears to be out of the question on the prairie farm. The fact should be recognized that neither field nor farmhome shelterbelts can be considered as woodlots, since such belts are planted for the protection they afford and the beauty they supply. Few would consider putting an axe into such belts, first, because the type of tree that provides the best shelter has little commercial value, and second, because even standing dead trees provide protection from winter winds.

While the conventional woodlot does not appear to be practical the possibility should not be ignored of utilizing the borders of the humid, submarginal depressions. Such locations can be used to advantage to grow belts of the fast growing and coppicing species of poplar and willow. These belts could be managed on a short rotation and could very possibly satisfy the farmer's personal fencepost and fuelwood requirements. ${ }^{2}$

The point has been made that few if any prairie farms contain non-arable land in sufficient acreage to support the conventional woodlot; nevertheless, there are scattered throughout the agricultural parkland areas occasional, comparatively large, non-arable areas that are presently supporting forest tree growth. These areas are usually sandy and therefore subject to extreme wind erosion if any attempt is made to cultivate them. Often they are situated over a high water table. Such forested lands as these could very well be set aside for management as community or municipal woodlots.

Having discussed the possibility of woodlots on the more heavily populated plains and parklands we turn to the forested region, and the fringe areas between the forested land and the strictly agricultural land. These fringe areas are commonly referred to as the "settlement" or "yellow" areas, the latter name stemming from the fact that this color has been used to delineate them on official provincial land maps. The great bulk of the forested area has been withdrawn from settlement by order-in-council and reserved for Crown timber production, and therefore is effectively removed from the present discussion. A great deal of the land in the yellow area is at present, or has been in the immediate past, timbered in commercial sizes and quantities. Consequently much of the soils are forest soils, although, in a great many cases, not seriously degraded, and therefore upon clearing are suited to agricultural purposes. The land is open to application for homestead lease or for purchase, provided that qualified appraisal indicates that at least 50 per cent of the acreage applied for is potentially arable, and that it contains less than 125,000 F.B.M. of timber per 160 acres. Land more heavily timbered is

2 See "The Prairie Farmer's Woodlot-Some Suggestions". For. Chron. XXIII, No. 1. 


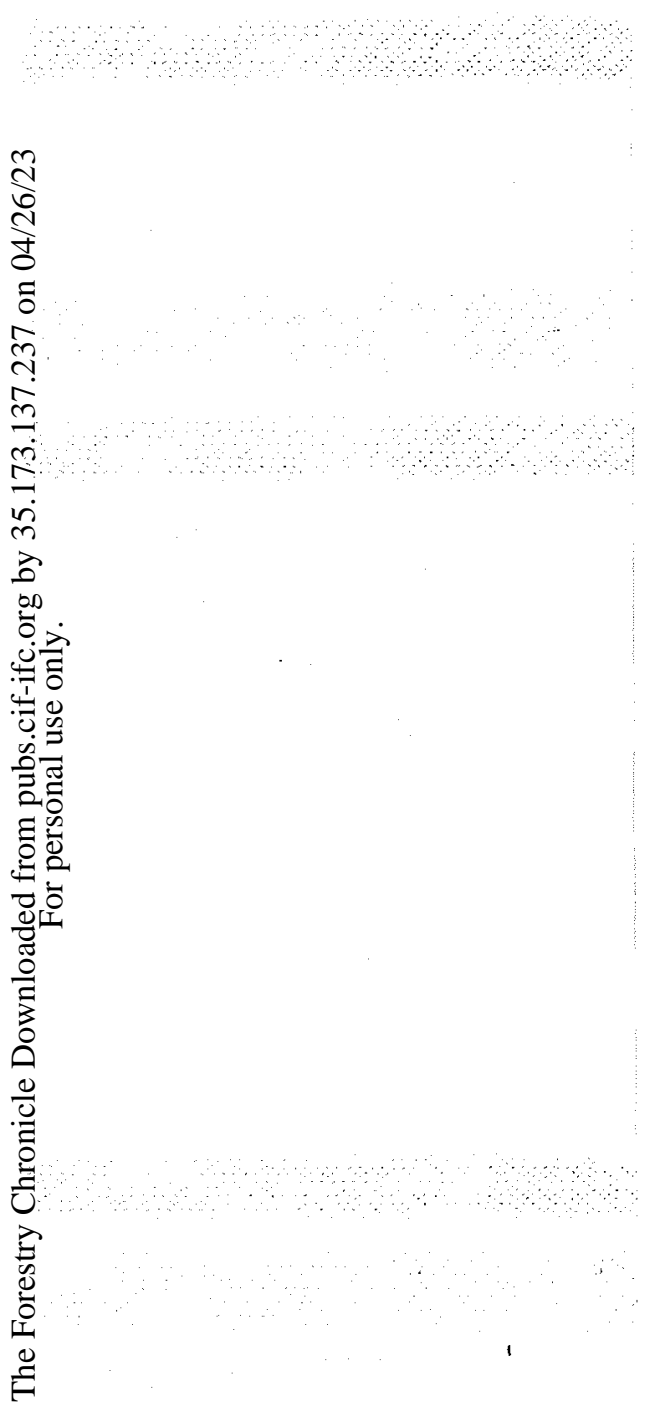

reserved by the Crown "for timber purposes". The homesteader on, or purchaser of, land that meets the above requirements therefore becomes our first potential woodlot operator, albeit on a rather small acreage. If all of his land is arable he may wish to clear it completely and get it into agricultural production; certainly his returns would be greater from cereal or forage crops than from timber. The Public Lands Act curbs such action by providing that the lessee "shall preserve and maintain for shelterbelts, windbreaks, and woodlots such areas of brush and forest cover as may from time be prescribed by the Director". ${ }^{3}$ It is my personal opinion that such action is not realistic; as in the parkland area natural woodlands are seldom situated to provide effective shelter, and if the land is potentially arable as little as possible should be wasted growing trees. A more practical alternative would be to permit the lessee to harvest the timber crop, provided that he use the returns to help def ray the cost of planting and maintaining an effective shelterbelt system at planned intervals across the whole area of his agricultural land.

Some patented lands are available for purchase in timbered areas and the restrictions previously mentioned do not apply. However, those lands that were commercially timbered have generally been heavily exploited, particularly during the post-war years when available stumpage has been at a premium. Clear-cutting has left a wilderness unattractive to a woodlot management program.

To sum up the existing situation in the province the individual farmer. in the plains and parkland regions has no existing nucleus for effective commercial woodlots; in the heavily forested areas the Crown prohibits settlement; and in the yellow areas the land is available but with restrictions that are rather prohibitive if one is contemplating woodlot management.

In order to encourage this form of forest culture within the province, while at the same time recognizing the inherent difficulties, the following forms of woodlot promotion are suggested:

1. The encouragement of plains and parkland farmers to utilize the borders of humid, sub-marginal depressions for growing coppicing species of trees in an attempt to make themselves self-sufficient in wood for ordinary farm consumption. Experimental and demonstration woodlots should be established and maintained by either federal or provincial authorities.

2. Presently forested areas on sub-marginal land lying within the grassland areas of the province to be set aside by either the province or the municipalities for management as community woodlots. Advice and guidance again should be provided by either federal or provincial authorities.

3. Consideration to be given to the enactment of legislation permitting the lessee to remove all the timber from his arable land, provided that he institute in its place an effective program of windbreaks. Some form of assistance might be warranted in such a program.

4. In the place of the present policy of requiring the homestead lessee to preserve and maintain a portion of his arable land for a woodlot, 
consideration be given to the following: any bona fide farmer, situated in the forested areas could become eligible for a nearby parcel of forest land already classified as non-arable and reserved for Crown timber production, provided that he agree to manage it under a definite woodlot management license. The amount of land that each farmer could acquire under such a license, the maximum distance from his farm home, as well as the terms of the license, would have to be established.

While existing legislation makes little provision for an effective woodlot program, criticism of such lack of action would be unjustified. 'There is a very limited market in this province for secondary forest products and without such a market there has been little need for woodlot promotion. However, with Alberta's rapid industrial expansion, this situation cannot continue much longer and now is the time to make provision for future requirements. 